\title{
Strategi Peliputan Berita Wartawan Majalah Suluh
}

\author{
Ahmad Nabiri Adi Manggolo \\ Universitas Islam Negeri (UIN) Sunan Kalijaga Yogyakarta \\ ahmadnabiriadi@gmail.com \\ Siswanto \\ Institut Agama Islam Negeri (IAIN) Curup \\ sis66505@gmail.com \\ Musthofa \\ Universitas Islam Negeri (UIN) Sunan Kalijaga Yogyakarta \\ mustofa@gmail.com
}

\begin{abstract}
A good news is not just born from ink built from mere editorial desks. Good news is built through the hot sun sweat and freezing cold of the night. Good news shows things that are not visible to the general public, down the valleys of depravity of human morals, and across every dimension of social, cultural, political life and whatever is the realm of life for every human being. SULUH magazine is an invisible dimension. Amid the glitter of commercial mass media, SULUH Magazine survives with classic discourses that are now processed into modern ones. Amid the crush of capital constraints, SULUH Magazine is still published with a relatively good circulation. The process of reporting the news from Malalah SULUH itself and the process of extracting the news, and more specifically through interviews. The results of this research include the magazine SULUH as a bimonthly interfaith magazine that is designed through a grand theme (big theme) that is gathered at the beginning of each year. SULUH magazine conveys important messages or issues in a rubric called the "TOPIC" rubric. In the "TOPIK" section of SULUH Magazine, we then analyze the transformation process from a reality or event into a news or article. Where in this process the writer also found a unique reporting style that the author did not find in the mass media in general, namely a report or news content that was taken from a literature study, rather than taking it from a reality that occurred in society.
\end{abstract}

Keywords: Strategy, News Coverage 


\begin{abstract}
Abstrak
Sebuah berita yang baik tidak lahir begitu saja dari tinta yang dibangun dari meja redaksi belaka. Berita yang baik dibangun melalui keringat panas terik matahari dan kebekuan dinginnya malam. Berita yang baik menampilkan hal-hal yang tak terlihat oleh khalayak umum, menyusuri lembah-lembah kebejatan moral manusia, dan melintasi setiap dimensi kehidupan sosial, budaya, politik dan apa saja yang menjadi wilayah kehidupan bagi setiap manusia. Majalah SULUH merupakan dimensi yang tak terlihat itu. Ditengah gemerlapnya media masa komersial, Majalah SULUH tetap bertahan dengan wacana-wacana klasik yang diolah sekan menjadi modern. Ditengah himpitan keterbatasan modal, Majalah SULUH tetap terbit dengan oplah yang relatif cukup baik. Proses peliputan berita dari Malalah SULUH itu sendiri dan proses penggalian beritanya, dan lebih khusus lagi yang melalui wawancara. Adapun hasil dari penelitian ini antara lain yaitu majalah SULUH sebagai majalah antar-iman (interfaith) yang terbit dwi-bulanan didesain melalui grand tema (tema besar) yang dirapatkan pada setiap awal tahun. Majalah SULUH menyampaikan pesan-pesan atau isu-isu pentingnya dalam satu rubrik yang disebut rubrik "TOPIK". Pada rubrik "TOPIK" Majalah SULUH, kemdian kami menganalisa proses tranformasi dari sebuah realita atau peristiwa menjadi sebuah berita atau tulisan. Dimana dalam proses ini jualah penulis menemukan starategi peliputan yang unik yang tidak penulis temukan pada media masa umumnya, yakni sebuah laporan atau berita yang content/isi berita banyak diambilkan dari studi kepustakaan, dari pada mengambilnya dari sebuah realita yang terjadi di masyarakat.
\end{abstract}

Kata Kunci: Strategi, Peliputan Berita

\title{
Pendahuluan
}

Peran media massa merupakan salah satu sumber informasi yang dapat memudahkan masyarakat untuk memperoleh berita, hiburan, pendidikan dan lain-lain. Sehingga media massa banyak bermunculan pada saat sekarang ini, salah satunya adalah majalah SULUH yang diterbitkan oleh Forum Persaudaraan Umat Beriman (FPUB) yang terbit secara berkala sejak tahun 2001. Dalam menjalankan peran, majalah SULUH mempunyai visi sebagai majalah yang membangun dialog antar iman dan persaudaraan sejati. Hal ini tidak terlepas dari peran FPUB sebagai penerbit yang fokus terhadap gerakan dialog antar iman. 
Dalam menyajikan berita, majalah SULUH menggunakan bilingual, yaitu bahasa Indonesia dan bahasa Inggris dalam penulisan berita serta laporannya. Penggunaan dua bahasa ini juga terdapat didalam rubrik "TOPIK", dimana rubrik ini sendiri merupakan rubrik utama dalam majalah tersebut. Sebagaimana fungsi dan peran media masa (majalah) lainnya, majalah SULUH juga berfungsi sebagai media informasi dan kritik sosial. Namun, sebagai majalah lintas iman, maka tema-tema yang diangkat pun selalu berkaitan dengan tema besar pluralisme, kerukunan beragama dan dialog antar iman ${ }^{1}$.

Mengingat tema dan informasi yang disajikan majalah SULUH mengandung nilai dan pesan tentang sesuatu yang bersifat doktriner, maka wartawan sebagai pencari dan penulis berita dituntut untuk menyajikannya sebaik dan semenarik mungkin. Hal ini tidak lain agar pembaca merasa enjoy ketika membaca berita atau pesan yang ditulis dalam majalah SULUH umumnya dan rubrik "TOPIK" pada khususnya. Sehingga ketika pembaca membaca produk jurnalismenya, pembaca tidak merasa digurui oleh pesan yang ditulis tersebut. Berdasarkan uraian diatas, berkenaan dengan media jurnalistik maka penulis mengambil judul skripsi "Strategi Peliputan Berita Wartawan Majalah SULUH Pada Rubrik "TOPIK". Dalam judul diatas mengandung pengertian bahwasannya dalam pencarian berita tentunya ada strategi yang digunakan oleh wartawan yang berkaitan langsung dalam pencarian berita.

Adapun alasan peneliti untuk mengadakan penilitian di majalah SULUH yaitu untuk mengetahui lebih jauh tentang penerbitan majalah SULUH, mulai dari sejarah berdirinya hingga proses pelaksanaannya, khususnya terkait peliputan dan penulisan pada rubrik "TOPIK".

${ }^{1}$ Dokumentasi Majalah SULUH diambil pada tanggal 21 Mei 2011. 


\section{Pembahasan}

1. Tinjauan umum tentang berita

a. Definisi Berita

Pada tahun 1882, Charles A. Dana pernah mengatakan: “When a dog bites a man that is not news but when a man bites a dog that is news" (Apabila seekor anjing menggigit orang itu bukanlah berita, akan tetapi apabila orang menggigit anjing itu baru berita). Hamzah Ya'qub dalam bukunya "Publistik Islam" menuliskan pengertian berita, yaitu pernyataan yang bersifat umum dan actual, dibuat oleh wartawan dan dimuat oleh surat kabar untuk dihidangkan kepada para pembaca. ${ }^{2}$ Bagaimana berita itu dapat menarik sehingga bisa layak dimuat dalam surat kabar atau majalah, tentunya mempunyai penilaian tertentu. Maka di sini bagaimana berita itu layak dimuat adalah sebagai berikut:

1) Akurat

Wartawan harus memiliki kehati-hatian yang sangat tinggi dalam melakukan pekerjaanya mengingat dampak yang luas yang ditimbulkan oleh berita yang dibuatnya. Kehati-hatian dimulai dari kecermatannya terhadap ejaan nama, angka, tanggal serta usia serta disiplin diri untuk senantiasa melakukan periksa ulang atas keterangan fakta yang ditemuinya.

2) Berimbang

Lengkap, adil dan berimbang adalah bahwa seorang wartawan harus melaporkan apa sesungguhnya yang terjadi. Peristiwa harus ditulis apa adanya, dalam beberapa hal dan kondisi.

3) Objektif

Wartawan dituntut untuk selalu bersikap objektif dalam menulis berita. Maka dengan sikap objektifnya, berita yang ia buat pun akan objektif, artinya berita yang dia buat itu selaras dengan kenyataan dan 
tidak berat sebelah, bebas dari prasangka, serta tidak memihak kepada siapapun.

4) Ringkas dan Jelas

Berita dibuat dan ada untuk melayani. Untuk melayani sebaikbaiknya, wartawan harus mengembangkan ketentuan-ketentuan yang disepakati tentang bentuk dan cara membuat berita. Berita yang disajikan haruslah dapat dicerna dengan cepat. Ini artinya suatu tulisan yang ringkas, jelas dan sederhana. Tulisan berita harus tidak banyak menggunakan kata-kata, harus langsung dan padu.

5) Aktual

Berita adalah padanan kata News dalam bahasa Inggris. Kata News itu sendiri menunjukkan adanya unsur waktu, apa yang baru. Berita memang selalu baru, selalu hangat. Media-media berita selalu ingin menyuguhkan berita yang hanya "hangat" tetapi juga paling sedikitnya yang terakhir. ${ }^{3}$

b. Nilai Berita

Sebuah berita disebut berita jika tidak dipublikasikan di media massa namun tak semua peristiwa atau informasi layak dilaporkan kepada publik melalui media massa. Media tidak hanya mempunyai struktur dan pola kerja, namun ia juga mempunyai konsep dan ideologi profesional.

Setiap peristiwa tidak lantas menjadi sebuah berita, tetapi ia harus dinilai terlebih dahulu apakah peristiwa tersebut memiliki kriteria dan memiliki unsur nilai berita. Tidak semu aspek peristiwa dapat dilaporkan, namun harus dinilai terlebih dahulu bagian mana dari peristiwa yang mempunyai nilai berita tinggi, bagian itulah yang ditekankan untuk dilaporkan. ${ }^{4}$ Secara umum kejadian yang dianggap memiliki nilai berita atau layak berita adalah yang mengandung beberapa unsur berikut :

\footnotetext{
${ }^{3}$ Hikmat Kusumaningrat dan Purnama Kusumaningrat, Jurnalistik Teori dan Praktek, (Bandung: Rosdakarya, 2006), 48-57

${ }_{4}$ Eriyanto, Analisis Framing, Cet. V (Yogyakarta: LKIS, 2008), 104.
} 
1) Akurat

Aktual disini artinya peristiwa tersebut baru, hangat, sedang atau baru saja terjadi. Dalam unsur ini terkandung makna berita, yaitu informasi tentang sesuatu yang baru terjadi, tetapi dapat pula merupakan berita kelanjutan dari hari atau waktu sebelumnya. Demikian tugas wartawan adalah membuat mejadi tahu atau lebih tahu.

2) Faktual

Bahwa berita harus berdasarkan fakta dan benar-benar terjadi bukan rekaan. Fakta muncul dari sebuah kejadian nyata, pendapat dan pernyataan. Dalam unsur faktual ini juga terkandung pengertian, sebuah berita harus merupakan informasi tentang sesuatu sesuai dengan keadaan yang sebenarnya dan fakta itu tidak dapat direkayasa.

3) Penting (Significant)

Unsur penting disini mencakup dua hal, yang pertama berkaitan dengan tokoh (orang) yang terlibat dalam peristiwa itu. Kedua berkaitan besar kecilnya dampak suatu peristiwa pada masyarakat, artinya seberapa besar peristiwa memberi efek yang diperbincangkan masyarakat.

4) Menarik

Menarik disini idefinisikan bahwa berita tersebut dapat memunculkan rasa ingin tahu dan minat membaca seperti menghibur dan memberi pencerahan.

5) Tenar (Prominence)

Nilai sebuah berita ini dapat diukur dari besaran peristiwa. Peristiwa yang diberitakan adalah peristiwa yang dipandang penting dan melibatkan banyak pihak sebagai contohnya kecelakaan yang menewaskan satu orang, tentu memiliki nilai berita berbeda jika dibandingkan kecelakaan dengan korban tewas satu bus. 


\section{6) Human Interest}

Peristiwa lebih memungkinkan disebut sebuah berita kalu, peristiwa itu lebih banyak mengandung unsur haru, sedih dan menguras emosi khalayak.

7) Konflik

Peristiwa yang mengandung konflik lebih potensial disebut, berita dibandingkan dengan peristiwa yang biasa-biasa saja. Peristiwa kerusuhan, peristiwa tentang perkelahian akan dipertimbangkan dengan peristiwa konflik suami istri disebuah kampung.

8) Unusual

Berita mengandung peristiwa yang tidak biasa dan jarang terjadi. Peristiwa tentang ibu ynag melahirkan enam bayi dengan selamt lebih disebut berita jika dibandingkan dengan peristiwa kelahiran seorang bayi.

9) Proximity (Kedekatan)

Peristiwa yang lebih layak diberitakan dibandingkan dengan berita atau peristiwa yang jauh, baik secara fisik maupun emosional dengan khalayak.

c. Jenis Berita

Berita pada umumnya dapat dikatagorikan menjadi tiga jenis yaitu hard news (berita berat), soft news (berita ringan), dan investigative reports (laporan penyelidikan). ${ }^{5}$

1) Hard News

Hard news (berita berat) adalah berita tentang peristiwa yang dianggap penting bagi masyarakat baik sebagai individu, kelompok maupun organisasi. ${ }^{6}$ Hard news juga mencakup kejadian internasional, keadaan masyarakat, masalah ekonomi, criminal, kerusakan lingkungan, maupun berita tentang ilmu pengetahuan. Secara umum pada hard news informasi 2005), 39.

${ }^{5}$ Deddy Iskandar Muda, Jurnalistik Televisi, (Bandung: Remaja Rosda karya,

${ }^{6}$ Ashadi Siregar, Bagaimana Meliput dan Menulis Berita Untuk Media Massa, (Yogyakarta: Kanisius, 1998), 154. 
masih mudah untuk diperoleh, sebab semuanya itu masih transparan dan bisa diperoleh dipermukaan saja. Dalam peristiwa semacam ini pemimpin perusahaan sulit ditemui untuk dimintai keteranagan, bahkan cenderung untuk menghindar dari pers sehingga repoter harus berusaha lebih keras lagi.

2) Soft News

Soft news (beita ringan) seringkali disebut juga dengan feature yaitu berita yang tidak terikat dengan aktualitas namun lebih menitik beratkan pada hal-hal yang dapat menakjubkan atau mengherankan dan memiliki daya tarik yang tinggi bagi pemirsanya. ${ }^{7}$ Bagi media televisi, soft news sangat diperlukan dalam setiap penyajian program berita, karena berita ringan juga berfungsi sebagai selingan diantara berita-berita yang disiarkan dari awal siaran. Secara psikologis, pemirsa dapat mendapat sajian berita berat dari awal hingga akhir akan merasa ketegangan yang tinggi sehingga perlu adanya suatu intemezo. Intermezzo itu didapat dari soft news tersebut. Durasi berita ringan ini sangat bervariasi, tetapi hamper tidak ada yang lebih panjang dari 2 menit dan lebih pendek dari 45 detik. ${ }^{8}$

3) Investigative Reports

Investigative reports atau disebut juga laporan penyelidikan (Investigasi) adalah jenis berita yang ekslusif. Datanya tidak bisa diperoleh dipermukaan saja, tetapi juga harus dilakukan berdasarkan penyelidikan. ${ }^{9}$ Berita penyelidikan untuk media televisi jauh lebih sulit dilakukan disbanding dengan radio maupun media cetak. Televisi membutuhkan gambar bahkan wajah orang yang diwawancarai.

\section{Strategi peliputan berita} 2005), 40.

${ }^{7}$ Deddy Iskandar Muda, Jumalistik. Televisi, (Bandung: Remaja Rosda Karya,

${ }^{8}$ Ibid., 42

'J.B. Wahyudi, Komunikasi Jurnalistik, (Bandung: ALUMNI, 1991), 130. 
Dalam menjalani kehidupan tentunya tidak lepas dengan apa itu yang namanya tujuan. Tanpa tujuan hidup seakan tidak terarah. Dan untuk mendapatkan tujuan, tentunya semua orang harus mempunyai strategi untuk mendapatkanya. Dalam pencarian berita pun diperlukan strategi agar para wartawan mendapatkan berita yang sesuai dengan yang diinginkan. Tanpa adanya strategi wartawan akan sulit mendapatkan apa yang menjadi tujuanya yaitu berita yang menarik, aktual dan sebagainya. Sebagian besar sebuah tujuan dapat tercapai ditentukan dengan adanya strategi. Strategi yang baik akan memperoleh hasil yang baik. Oleh karena itu, ada baiknya memahami terlebih dahulu apa yang di maksud dengan strategi.

Strategi pada hakekatnya adalah perencanaan (planning) dan manajemen (management) untuk mencapai suatu tujuan. Akan tetapi untuk mencapai tujuan tersebut, strategi tidak berfungsi sebagai peta jalan yang hanya menunjukkan arah saja, melainkan harus mampu menunjukkan bagaimana taktik operasionalnya. ${ }^{10}$ Strategi berasal dari bahasa Yunani: Stratos (artinya pasukan) dan agein (artinya memimpin). Jadi strategi berarti hal memimpin pasukan. Ilmu strategi adalah ilmu tentang memimpin pasukan. Ilmu tentang perang. Dan kadang-kadang dikatakan orang sebagai ilmunya para jenderal, ilmu para komandan. ${ }^{11}$

Adapun strategi dasar sebagai wartawan dalam mencari berita sehingga beritanya dapat diterima oleh masyarakat, maka seorang wartawan dituntut harus bersikap: ${ }^{12}$

\section{a. Prinsip Ikhlas}

Prinsip ikhlas penting sekali bagi setiap wartawan guna menjaga titik keberangkatan, memantapkan niat agar karyanya benar-benar terwujud

\footnotetext{
${ }^{10}$ Onong Uchjana Effendy, Ilmu Komunikasi Teori dan Praktek, (Bandung, PT Remaja Rosdakarya, 2006) 32

${ }^{11}$ Ali Moertopo, Strategi Kebudayaan, (Jakarta, CSIS, 1978), 7 2006), $52-56$

${ }^{12}$ Yunus Hanis Syam, Panduan Berdakwah Lewat Jurnalistik, (Yogyakarta: Pinus,
} 
sebagai karya yang dapat memberikan manfaat dan berguna untuk kepentingan semuanya.

b. Kesiapan Teknis

Mempersiapkan segala hal yang memang dibutuhkan dalam proses kerja dari seorang wartawan itu juga sangat penting. Hal ini adalah sebagai fasilitas yang memang sangat membantu dia dalam bekerja. Seperti halnya: bolpoint, block note, rekaman, kamera, komputer dan lain-lain.

c. Memproses Berita Tahap Demi Tahap

Dalam proses wartawan dalam bekerja sangat dibutuhkan dengan adanya ketenangan dan kesabaran. Walaupun wartawan pekerjaanya selalu berhubungn dengan waktu, namun ketenangan dengankesabaran tetap di butuhkan di sini. Karena dengan itu wartawan dapat berpikir secara jernih dan memproses berita tahap demi tahap. sehingga berita dapat diperoleh dan ditulis dengan maksimal.

Dalam mencari berita, tidak jarang dan bahkan harus seorang wartawan melakukan wawancara. Adapun hal-hal teknis yang harus dipersiapkan dalam mencari berita, antara lain:

a. Sebelum melakukan liputan, wartawan harus memiliki bekal tentang apa saja yang akan dilakukanya.

b. Wartawan juga harus menguasai "TOPIK" pembicaraan. Dengan demikian, wartawan tidak buta sama sekali terhadap pokok persoalan yang akan ditanyakan kepada narasumber.

c. Pelajari dulu peristiwa dalam konteks pemberitaan. Apakah peristiwa itu memiliki nilai berita sehingga layak untuk diangkat sebagai berita.

d. Sebelum melakukan liputan, amatilah dahulu apakah berita itu sesuai dengan kode etik media massa tempat anda bekerja.

e. Jika berita tersebut sudah dianggap layak untuk diangkat, pertimbangkanlah apakah berita tersebut mendatangkan keuntungan bagi 
media. Keuntungan disini memiliki arti, berita tersebut nantinya banyak dibaca orang sehingga media laku keras.

f. Apakah berita yang diliput memiliki nilai "prominence" (kemahsyuran atau popularitas) kalau mengandung itu, bisa saja mendongkrak oplah penjualan media tersebut. ${ }^{13}$

Berita diperoleh wartawan tidak saja dari peristiwa yang dilihat dengan mata kepalanya sendiri. Akan tetapi juga dapat diperoleh dari banyak sumber-sumber lainnya seperti buku, internet dan jurnal.

Sebagaimana diketahui, berita juga terdiri dari berbagai macam yang antara lain berita politik, berita ekonomi, berita kejahatan, berita olahraga, berita militer, berita pendidikan, dan berita keagamaan. Masing-masing macam berita itu mempunyai sumber-sumber tersendiri. ${ }^{14}$ Untuk itu, wartawan dapat mencari bahan berita dari sumber berita yang lain seperti buku, internet, saksi dan lain sebagainya. Dengan adanya metode di atas, wartawan dalam kerjanya bisa lebih mudah dan cepat dalam mendapatkan beritanya, wartawan bisa mengerti mana ide berita yang bisa ia pilih, liput, tulis dan mana yang layak untuk dimuat. Namun khusus untuk para informan, para wartawan harus selalu menjaga hubungan yang baik dengan para informan tersebut, agar selalu terjaga kerja samanya sehingga wartawan bisa mendapatkan berita dengan optimal.

\section{Metode Penelitian}

a. Sumber Data dan Fokus Penelitian

Subyek penelitian adalah informan yang memberikan keterangan. Dalam hal ini yang akan diminta untuk memberikan informasinya adalah wartawan rubrik "TOPIK" Majalah SULUH. Sedangkan obyek dalam penelitian ini 2005), 17

13 Eni Setiati, Ragam Jurnalistik. Baru dalam Pemberitaan, (Yogyakarta: ANDI, 1995), 45

14 Sutirman Eka Ardhana, Jurnalistike Dakwah, (Yogyakarta: Pustaka Pelajar, 
adalah pada strategi pencarian berita wartawan pada rubrik "TOPIK” Majalah SULUH.

b. Metode Pengumpulan Data

1) Metode Interview (Wawancara)

Menurut Sutrisno Hadi, Wawancara adalah metode pengumpulan data dengan jalan tanya jawab yang dikerjakan secara sistematik dan berdasarkan kepada tujuan penelitian. ${ }^{15}$ Jenis interview yang digunakan adalah interview berpedoman terpimpin, yaitu pewawancara menentukan sendiri urutan dan juga pembahasan selama wawancara, ${ }^{16}$ Wawancara ini digunakan untuk mewawncarai pemimpin redaksi, redaktur dan wartawan majalah SULUH. Aspek yang diwawancarai meliputi sejarah majalah SULUH, tujuan rubrik "TOPIK", pemabagian tugas dalam meliput berita dan strategi apa saja yang digunakan dalam meliput berita majalah SULUH pada rubrik "TOPIK".

2) Metode Observasi

Metode observasi adalah pengamatan dan pencatatan secara sistematis mengenai fenomena-fenomena yang diselidiki. ${ }^{17}$ Observasi dilakukan terhadap kenyataan-kenyataan yang terlihat dan terdengar. Berbagai macam ungkapan dan percakapan sehari-hari juga termasuk bagian dari kenyataan yang bisa diobservasi. ${ }^{18}$ Sehingga penulis bisa lebih tahu bagaimana yang sebenarnya dan mendapatkan data yang lebih lengkap. Yang dijadikan bahan observasi adalah tentang strategi wartawan rubrik "TOPIK" dalam mencari beritanya.

${ }^{15}$ Sutrisno Hadi, Metodologi Research II, (Yogyakarta: Andi 2000), 44

16 Britha Mikhelsen, metode Penelitian pasipatoris dan Upaya-upaya Pemberdayaan, (Jakarta: Yayasan Obor Indonesia, 1999), 128.

17 Sutrisno Hadi, Metodologi Research Jilid II, (Yogyakarta: Fakultas Psikologi UGM, 1978), 136.

${ }^{18}$ Burhan Bungin, Analisis Data Penelitian Kualitatif (PT Raja Grafindo Persada, 2005), 66. 
3) Metode Dokumentasi

Metode dokumentasi adalah mencari data tentang variable yang berupa, catatan, agenda, notulen dan yang relevan dalam tujuan penelitian. ${ }^{19}$ Dalam hal ini berupa arsip, dokumen, catatan-catatan penting yang ada pada Majalah SULUH dan berhubungan dengan permasalahan penelitian yaitu strategi peliputan berita wartawan majalah SULUH. Data yang berhubungan dengan penelitian terhadap strategi wartawan majalah SULUH, dapat diperoleh dari dokumen yang ada di Majalah SULUH Jogja pada edisi 2009.

4) Metode Analisis Data

Analisis data adalah menyederhanakan dalam bentuk yang lebih sederhana untuk mudah dibaca dan dimengerti sehingga mudah untuk diambil kesimpulan. Untuk menganalisis data yang diperoleh dari hasil penelitian, penulis menggunakan analisis data kualitatif,, ${ }^{20}$ karena data yang diperoleh peneliti masih berupa uraian-uraian deskriptif. ${ }^{21}$ Maka penulis mengumpulkan semua data yang diperoleh kemudian melakukan penyusunan sesuai dengan urutan pembahasan, selanjutnya dianalisis dan ditafsirkan dalam bentuk kalimat yang sederhana dan mudah dimengerti.

\section{Hasil Penelitian}

\section{A. Manajemen Peliputan Berita Majalah SULUH}

Majalah SULUH merupakan salah satu media informasi massal yang diterbitkan oleh Forum Persaudaraan Umat Beriman (FPUB) Yogyakarta. Majalah ini diterbitkan dua bulan sekali (dwi bulanan) dan menggunakan dua bahasa (bilingual), yakni bahasa Indonesia dan bahasa Inggris. Strategi -strategi mencari berita, khususnya melalui wawancara dan menganalisis hasil-hasil

${ }^{19}$ Sutrisno Hadi, Metodologi Penelitian jilid II (Jakarta: Andi offset, 1994), 136.

${ }^{20}$ Pius A Partanto dan M Dahlan Al Barry, Kamus Ilmiab Populer (Surabaya: Arkola, 1994), 384.

${ }^{21}$ Ibid., hlm. 105. Deskriptif: Bersifat menggambarkan/menguraikan sesuatu hal menurut apa adanya. 105. 
liputan tersebut yang telah dituangkan dalam bentuk laporan/berita pada rubrik "TOPIK" Majalah SULUH FPUB Yogyakarta. Sebuah berita atau laporan tidak lahir begitu saja, tidak dibuat dengan duduk manis sambil mendengarkan musik atau muncul dengan sendirinya. Untuk dapat membuat laporan seperti diatas, seorang wartawan atau kru media setidaknya harus melalui beberapat tahapan, antara lain:

a) Perencanaan

Pada tahap ini crew Majalah SULUH mengawali rapat redaksi setiap dua bulan sekali setelah edisi sebelumnya sampai pada proses percetakan. Sehingga rapat redaksi ini dilaksanakan kira-kira seminggu sebelum majalah Suluh diterbitkan. Disamping rapat redaksi sebelum percetakan, Majalah SULUH juga melakukan diskusi setiap jum'at sore pada setiap minggu. Diskusi ini bersifat non formal dan merupakan bagian wajib dari belangsungnya peliputan dan produksi Majalah SULUH. Diskusi ini diikuti semua crew yang terlibat dalam produksi Majalah SULUH. Dan untuk mengetahui semua yang diharapkan masyarakat (public), maka redaksi dituntut untuk melakukan sebua perencanaan yang matang terkait tema berita yang akan diliput atau disajikan sebagai produk andalan jurnalismenya. Pada Majalah SULUH, perencanaan sebuah tema berita dilakukan pada saat rapat redaksi yang dilaksanakan di kantor FPUB Yogyakarta. Kantor FPUB sendiri merupakan sebuah bangunan yang juga difungsikan sebagai kantor Majalah SULUH. Rapat ini dihadiri oleh semua jajaran kepengurusan yang ada pada Majalah SULUH, mulai dari Pimpinan Umum, Pimpinan Redaksi dan kru-kru lainnya yang ada pada Majalah SULUH, termasuk juga bagian iklan dan pemasaran. Rapat redaksi dipimpin oleh Pimpinan Redaksi (Pimred). Namun, terkadang juga dipimpin oleh Pimpinan Umum (PU). Rapat redaksi pada Majalah SULUH membahas hal-hal teknis dan non-teknis terkait penerbitan Majalah SULUH. 
Hal-hal teknis meliputi, pencarian berita, cetak majalah, pencarian iklan dan sebagainya. Adapun hal-hal non-teknis meliputi, tema yang akan diangkat dan menentukan rubrik yang akan dimuat dan lain-lain. Rapat ini membahas sejumlah isu yang sedang berkembang, lalu menganalisisnya, untuk kemudian dirumuskan kedalam sebuah tema besar yang nantinya dijadikan pedoman wartawan Majalah SULUH dalam mencari informasi/berita ${ }^{22}$. Persiapan dan Peliputan. Setelah tema besar yang akan diangkat telah disepakati, maka langkah selanjutnya adalah melakukan persiapan dan pencarian informasi atau bahan penulisan berita. Pada rubrik "TOPIK" sendiri penulisan berita atau laporannnya lebih banyak kepustakaan.

Untuk membuat sebuah berita yang mendalam, wartawan Majalah SULUH juga membuat outline sebelum ke lapangan. Sehingga pada saat di lapangan, wartawan tidak kosong terhadap realitas (kasus atau fenomena) yang akan diurai. Adapun pengetahuan awal tentang fenomena yang akan diurai akan sangat membantu dalam pembacaan fenomena tersebut. Hal ini mengingat tidak mungkin seluruh uraian fenomena yang terjadi dapat disajikan dalam bentuk tulisan. Wartawan Majalah SULUH juga dibekali kamera untuk mengabadikan fenomena-fenomena yang terjadi pada saat liputan. Gambar menjadi penting sebagai penguat semua kejadian yang terjadi selama proses reportase. Hal ini setidaknya dapat dijadikan sebagai pelengkap dari uraian yang ditulis pada sebuah berita atau laporan.

b) Penulisan dan Penyajian

Penulisan berita merupakan tugas tersendiri dari pekerjaan jurnalis. Bagaimanapun pencarian informasi merupakan elemen pokok dalam pekerjaan jurnalistik. Peristiwa atau fenomena yang dilihat, diamati dan dirasakan oleh wartawan Majalah SULUH selama proses peliputan

22 Wawancara dengan Putri Alit Mranani, Pimred Majalah SULUH 2011 pada 10 Juni 2011 di kantor FPUB Yogyakarta. 
kemudian disajikan kedalam bentuk tulisan. Hal ini mengingat Majalah SULUH adalah media masa cetak. Adapun proses penulisan berita pada Majalah SULUH, pada prinsipnya tidak banyak berbeda dengan media masa lainnya. Apabila di media masa yang sudah mapan, maka sudah ada prosedur operasional standar (SOP) dalam pembuatan berita. Pada Majalah SULUH juga ada standar operasainya. Hal ini dilakukan untuk menjaga kualitas berita yang dihasilkan oleh wartawan Majalah SULUH. Berita atau laporan yang ditulis wartawan Majalah SULUH tidak serta merta sebuah berita seagaimana berita pada umumnya. Berita-berita yang disajikan pada setiap rubrik Majalah SULUH selalu dibarengi dengan muatan-muatan ideologi-ideologi yang bervisi pluralisme, kebebasan beragama dan dialog antar iman (inter faith). Teknik reportase atau teknik peliputan berita pada Majalah SULUH merupakan hal mendasar yang perlu dikuasai oleh para wartawan-wartawannya. Majalah SULUH juga memiliki apa yang disebut kriteria kelayakan berita. Selain itu, Majalah SULUH juga memiliki apa yang disebut kebijakan redaksional (editorial policy). Kriteria kelayakan berita pada Majalah SULUH itu masih bersifat umum (universal), dan tak jauh berbeda dengan media-media yang lain. Sedangkan kebijakan redaksional pada Majalah SULUH sangat tergantung dari visi, misi dan ideologi yang dianut Majalah SULUH FPUB Yogyakarta 23 .

\section{B. Strategi Peliputan Berita Wartawan Majalah SULUH Dengan Wawancara}

1. Tahap Persiapan Wawancara

Dalam sebuah peliputan, wawancara (interview) merupakan bagian tidak terpisahkan dari sebuah proses penggalian sebuah berita. Wawancara (interview) merupakan salah satu metode pengumpulan bahan berita (data atau fakta). Proses wawancara dalam Rubrik Topik

${ }^{23}$ Dokumentasi Majalah SULUH. 
dapat diartikan sebagai rangkaian kegiatan wawancara yang dilakukan oleh wartawan majalah SULUH meliputi sebelum, saat dan sesudah wawancara dilakukan oleh peliput untuk mencari ataupun menggali berbagai pendapat atau pandangan tokoh-tokoh tertentu tentang permasalahan yang sedang dibahas pada Rubrik Topik. Tahap persiapan merupakan tahap yang penting yang harus dilakukan oleh wartawan, agar proses wawancara dapat berjalan lancar dan memenuhi tujuan wawancara. Seperti ibarat tentara yang akan berangkat menuju medan perang, maka dia harus membawa berbagai macam senjata yang digunakan untuk mengalahkan musuh. Begitu juga dengan wawancara, ada beberapa hal yang harus dipersiapkan oleh wartawan, diantaranya:

a. Menentukan masalah

"Salah satu persiapan pokok yang harus dipersiapkan oleh wartawan Rubrik Topik adalah mengusai tema yang akan diangkat. Hal ini sesuai dengan TOR yang telah dipresentasikan oleh wartawan yang bertugas pada saat rapat redaksi, hal ini bertujuan agar wartawan dapat melakukan wawancara dengan sebaikbaiknya". ${ }^{24}$ Untuk menguasai materi yang akan ditanyakan kepada narasumber, wartawan dituntut untuk banyak membaca buku yang terkait dengan materi. Dari buku-buku tersebut, wartawan dapat membuat daftar pertanyaan penting yang akan ditanyakan. Informasi atau pendapat yang disamapaikan oleh narasumber dapat dikembangkan atau diperluas dengan munculnya pertanyaan baru.

Dari penyataan tersebut dapat disimpulkan bahwa, sebelum melakukan wawancara dengan narasumber, wartwan Majalah Suluh harus melakukan pendalaman materi yang dilakukan dengan membaca

${ }^{24}$ Wawancara dengan Putri Alit Mranani, Pimpinan Redaksi Majalah SULUH FPUB Yogyakarta, pada tanggal 15 Juli 2011. 
buku, koran atau artikel yang memiliki keterkaitan dengan tema yang sedang diangkat. Hal ini penting dilakukan agar wartawan dapat melakukan wawancara dengan baik karena menguasai persoalan yang sedang ditanyakan. Dengan banyak membaca buku, koran atau artikelartikel dapat menambah wawasan pengetauan dan pemahaman wartawan menjadi luas. Ini menjadi senjata bagi wartawan agar dapat melakukan perbincangan yang seimbang dalam wawancara, sehingga narasumber menjadi terpacu untuk banyak berpendapat karena mendapat rangsangan (stimulus) dari pewawancara. Wartawan yang tidak membaca buku, koran atau informasi yang terkait dengan masalah, akan mengalami kendala dalam pengembangan pertanyaan. Wawancara yang dilakukan hanya berjalan monoton, kaku dan kurang menarik, karena pewawancara hanya terpaku pada daftar pertanyaan yang telah dibuat. Penentuan masalah atau tema dilakukan melalui pembuatan proposal rencana tema (TOR), dibuat oleh wartawan yang bertugas. Setelah wartawan memahami TOR tersebut, langkah selanjutnya yang dilakukan adalah mempersiapkan yang akan diajukan kepada narasumber. hal ini bertujuan: ${ }^{25}$

a) Pembahasan menjadi sistematis

Pembahasan yang sistematis akan membuat narasumber merasa nyaman dalam menjawab pertanyaan yang diajukan, selain itu dalam pengolahan hasil wawancara menjadi mudah. Wartawan dalam menyiapkan dan memahami permasalahan yang akan ditanyakan merupakan poin penting yang harus dilakukan.

b) Pertanyaan menjadi sinergis

Dengan adanya suatu hubungan sinergis antara pertanyaan yang satu dengan yang lain, maka akan lebih sistematis. 
Wartawan yang tidak menyiapkan pertanyaan terlebih dahulu, maka dalam mengajukan pertanyaan akan melompat-lompat dan tidak fokus. Sehingga wartawan yang diwawancarai merasa tidak nyaman.

c) Menghindari pengulangan pertanyaan

Narasumber merasa tidak nyaman apabila wartawan mengulangi pertanyaan yang sama tanpa sadar, hal ini akan membuat citra wartawan tersebut kurang baik. Dengan adanya persiapan pertanyaan maka wartawan tidak akan melakukan kesalahan dengan mengulang pertanyaan yang sama, tentunya wawancara yang dilakukan akan berjalan lancar sesuai dengan tujuan.

Dari pemaparan tersebut dapat dipahami bahwa wartawan Majalah SULUH sangat memperhatikan aspek persiapan berupa pertanyaan terbaik.

\section{Menentukan angle}

Dalam menentukan angle atau arah bahasan merupakan salah satu persiapan yang sangat penting dilakukan wartawan untuk melakukan wawancara, hal ini untuk menjaga agar pembicaraan dapat terarah dan tidak melenceng dari tujuan wawancara. Menentukan angle ini dilakukan oleh wartawan Rubrik Topik, agar dapat mengarahkan narasumber kepada pembicaraan yang wartawan maksudkan. Penentuan angle sebenarnya telah ditentukan melalui pembagian tugas pada saat rapat redaksi, hal ini dimaksudkan agar pembahasan dalam satu tema yang sedang diangkat lebih sinergis, tetapi dilihat dari arah angle yang berbeda sehingga satu dengan yang lainnya akan saling melengkapi. Sedangkan wartawan yang bertugas melakukan wawancara harus dapat membahasnya dengan baik sehingga narasumber yang diwawancara menjadi terpancing untuk memberikan pendapatnya lewat angle yang telah dipaparkan oleh wartawan. Pada tahap ini para wartawan dan awak SULUH saling berkontribusi memberikan gagasannya dengan 
cara mengusulkan angle dan materi yang layak sebagai bahasan dalam edisi yang akan dikerjakan. Pada majalah SULUH diskusi penentuan tema pada Rubrik Topik selama edisi 2009 dipimpin oleh Muhammad Ahsan selaku pimpinan redaksi majalah SULUH.

3. Menentukan narasumber

Dalam Rubrik Topik, penentuan narasumber dilakukan oleh pembuat proposal rencana tema (TOR) dan melaui penjaringan pendapat pada rapat redaksi, sehingga wartawan pada saat melakukan wawancara dapat langsung menemui narasumber yang telah ditentukan, tanpa harus menentukan sendiri narasumber yang harus diwawancarai. Tentunya dalam menentukan narasumber ini berpatokan pada tema dan isu aktual pada edisi yang akan diangkat. ${ }^{26}$ Penentuan narasumber dilakukan berdasarkan aspek-aspek berikut ini:

a) Aspek kompetensi

Artinya narasumber yang akan diwawancarai memiliki kompetensi terhadap permasalahan yang sedang diangkat, misalnya tema yang sedang diangkat mengenai pertanian secara otomatis narasumber yang dipilih orang yang ahli di bidang pertanian.

b) Aspek kapasitas

Narasumber yang diwawancarai sesuai dengan tema yang sedang diangkat, contoh dalam menyikapi suatu permasalahan pendidikan, maka harus melibatkan pandangan-pandangan tokoh yang berkecimpung dalam pendidikan yang menduduki posisi tertentu pada lembaga tertentu.

c) Dalam hal intregritas selalu diperhatikan, karena komentar yang didaptkan harus berasal dari orang yang memiliki wawasan yang

26 Wawancara dengan Putri Alit Mranani, Pimpinan Redaksi Majalah SULUH FPUB Yogyakarta, pada tanggal 15 Juli 2011. 
luas dan terpercaya. Misalnya dosen suatu universitas, agamawan, budayawan, peneliti dan lain sebagainya.

d) Narasumber tidak harus berada dalam satu kejadian, karena tulisan pada Rubrik Topik bukanlah suatu berita, melainkan hanya tulisan investigatif dan reflektif. Sehingga yang dibutuhkan adalah pendapat para tokoh ataupun orang-orang yang memiliki kompetensi dan kapasitas dalam bidangnya masing-masing. Dari pemaparan diatas dapat disimpulkan bahwa dalam menentukan narasumber pada Rubrik Topik tidak sembarang narasumber, akan tetapi harus sesuai dengan beberapa kriteria yang telah ditentukan, walaupun narasumber tersebut telah ditentukan akan tetapi tidak menutup kemungkinan adanya usulan-usulan calon narasumber baru dalam rapat redaksi,hal ini dilakukan sebagai langkah untuk mengantisipasi bila suatu saat narasumber berhalangan untuk diwawancarai. Aspek pokok yang menjadi acuan untuk menentukan narasumber adalah kompetensi dibidang yang digeluti dan kapasitas narasumber tersebut. Hal ini sangat sesuai dengan tulisan pada Rubrik Topik yang merupakan tulisan investigatif dan reflektif.

e) Pengenalan sifat dan karakter narasumber

Dalam melakukan wawancara, seorang wartawan sebaiknya mengetahui berbagai perwatakan dari narasumber yang akan diawancarai, hal ini penting agar proses wawancara yang dilakukan lebih mudah dan efektif. Dari keterangan diatas bahwa wartawan Rubrik Topik menganggap penting mengenal sifat dan karakter narasumber. akan tetapi dalam kenyatannya wartawan tidak dapat seenaknya dalam melakukan wawancara tanpa memahami bagaimana keadaan yang sedang dihadapi oleh narasumber.

Menurut R.Fadli, wartawan harus memahami bagaiman karakter narasumber, melalui vokal, gaya maupun logat bicaranya. Karakter 
yang dimaksud dapat memberitahukan bahwa kepada pewawancara apakah narasumber nyaman diajak bicara, apakah cara bicaranya kaku atau terkesan formal ataukah ramah dan tenang, apakah karakternya meledak-ledak, apakah dia murah atau pelit bicaranya. Karakter tersebut sangat dipengaruhi oleh latar belakangnya misal dari segi pendidikan, keluarga, teman, status sosial dan lain sebagainya. Hal-hal lain yang dapat mempengaruhi sikap narasumber adalah faktor-faktor yang sifatnya individual, misal salah seorang anak dari narasumber sedang sakit parah atau karena adanya masalah berat yang dihadapi.

f) Menghubungi dan membuat janji dengan narasumber Salah satu persiapan penting yang harus dilakukan adalah menghubungi dan membuat janji dengan narasumber. hal ini dilakukan agar dapat mengetahui kapan dan dimana wawancara akan dilakukan, selain itu wartawan dapat mempersiapkan apa saja yang perlu dibawa. Wartawan Rubrik Topik dapat menghubungi dan membuat janji dengan cara menelpon ataupun sms kepada narasumber. Wartawan juga dapat mempertegas janji tersebut dan memberi pemberitahuan jika ada perubahan jadwal.

g) Mempersiapkan peralatan yang diperlukan

Mempersiapkan alat dan peralatan wawancara dilakukan oleh wartawan. Seorang wartawan biasanya mempersiapkan peralatan yang dibutuhkan dilapangan seperti peralatan untuk mencatat hasil wawancara. Beberapa alat yang dibutuhkan seperti, kamera, perekam dan alat tulis lainnya.

Proses persiapan wawancara pada Rubrik Topik sampai saat ini meliputi persiapan peralatan yang terdiri dari mempersiapkan alat rekam dan kamera. Persiapan biasa dilakukan sebelum wawancara dengan narasumber, karena pada intinya peralatan ini yang akan sangat membantu dalam penulisan Rubrik Topik. 
"Pengecekan kembali dari kerja alat yang akan digunakan selalu dilakukan. Tindakan ini diambil karena wartawan tidak mungkin melakukan dua kali. Pada Rubrik Topik cukup mempersiapkan alat rekam jenis MP 4 dan kamera digital. Persiapan biasanya dilakukan berupa percobaan fungsi dari alat perekam beberapa kali kemudian dicoba untuk disetel kembali di komputer. Setelah memastikan alat rekam berada pada kondisi ready dan siap digunakan maka wartawan segera mengemas bersama kamera digital."27

Dari penjelasan diatas bahwasanya wartawan Rubrik Topik sangatlah memperhatikan kesiapan alat-alat yang diperlukan untuk melakukan wawancara agar dapat berjalan baik dan lancar.

\section{Tahap Pelaksanaan}

1. Sopan santun

Bersikap sopan santun merupakan etika yang selalu dijunjung tinggi oleh masyarakat Indonesia, karena hal ini berkaitan erat dengan harga diri seseorang dihadapan orang lain. Seorang wartawan yang sedang melakukan wawancara memiliki kepentingan terhadap narasumber, hal ini terkait dengan informasi ataupun pendapat yang harus digali secara mendalam dari narasumber yang diwawancarai. Selain bersikap sopan, hal yang perlu diperhatikan adalah cara berpakaian artinya pakaian sseorang dapat menjadi cerminan pribadi orang tersebut.

2. Memperkenalkan diri

Memperkenalkan diri merupakan suatu yang lazim dilakukan sebagai salah satu etika yang baik, selain itu dengan mengetahui nama seseorang maka pembicaraan akan lebih cair dan enjoy. Pada tahap ini wartawan terlebih dahulu memaparkan maksud dan tujuan dari wawancara yang akan dilakukan. Wartawan Rubik Topik didalam 2011.

${ }^{27}$ Wawancara dengan pimpinan umum saudara M. Ihrom pada tanggal 23 Juni 
melakukan wawancara, selalu memperkenalkan diri tentang nama dirinya dan media yang diwakili, dalam hal ini majalah SULUH.

3. Menunjukkan kesan yang baik terhadap narasumber Seseorang yang tidak memiliki minat untuk mendapatkan informasi dari oarang lain, akan membuat orang yang sedang diajak bicara menjadi enggan dan ragu dalam memberikan informasi. Apabila hal ini dilakukan oleh wartawan tentunya akan berimbas pada hasil wawancara berupa informasi atau pendapat dari narasumber tidak memadai tau sangat minim.

Wartawan Rubrik Topik selalu menganggap wawancara itu penting, selain dapat menunjukkan etika yang baik sebagai wartawan. Hal ini juga akan menjadi daya tarik tersendiri serta dapat menimbulkan rasa nyaman dari narasumber, sehingga wawancara dapat berjalan dengan lancar dan sesuai tujuan. ${ }^{28}$ Kesan yang baik terhadap narasumber tentunya tidak dapat dibuat-buat akan tetapi merupakan ketulusan hati dari pewawancara. Wartawan yang baik akan mengaggap penting

4. Membuat narasumber merasa nyaman

Kenyamanan yang dirasakan oleh narasumber akan membuat wawancara akan menjadi lebih menyenangkan dan efektif. Hal ini perlu adanya upaya khusus yang dilakukan oleh wartawan.

5. Meminta ijin untuk merekam atau mencatat

6. Mulai mengajukan pertanyaan

Hal pokok yang harus dilakukan oleh wartawan yaitu mengajukan pertanyaan yang telah dipersiapkan sebelumnya. Pertanyaan-pertanyaan tersebut disesuaikan dengan TOR yang telah dikaji secara mendalam oleh wartawan sebelum melakukan wawancara. Wawancara yang dilakukan oleh wartawan memang tidak mendasarkan pertanyaan

${ }^{28}$ Wawancara dengan Putri Alit Mranani, Pimpinan Redaksi Majalah SULUH FPUB Yogyakarta, pada tanggal 25 Juli 2011. 
dengan konsep $5 \mathrm{~W}+1 \mathrm{H}$. Menurut isgandi, pertanyaan yang dilontarkan tidak terlalu kaku harus seperti dalam panduan pertanyaan. Akan tetapi dapat dikembangkan secara lebih mendalam.

\section{Daftar Pustaka}

Alief, “Teknik Mengumpulkan Berita”. http//aliefnews.wordpress.com

Arikunto, Suharsimi, Prosedur Penelitian. Jakarta: PT. Melton Putra

Assegaf, Djafar, Jurnalistik Masa Kini. Jakarta: Ghalia Indonesia, 1983.

Brandt, Torben, Makalab Jurnalisme Radio Sebuah Panduan Praktis. Yogyakarta: UGM, 2002.

Bungin, Burhan, Analisis Data Penelitian Kualitatif PT Raja Grafindo Persada, 2005

Dwi, Kristina, Dasar-dasar jurnalistik. http://id.Pelitaku. sabda. org

Effendy, Onong Uchjana, Ilmu Komunikasi Teori dan Praktek, Bandung: PT Remaja Rosdakarya, 2006.

Hadi, Strisno, Metodologi Research Jilid II, Yogyakarta: Fakultas Psikologi UGM, 1978.

Haris, AS Sumadiria, Jurnalistik Indonesia: Menulis Berita dan Feature, (Bandung: Simbiosis Rekatema, 2006.

Irawan Riyati, dkk., Tanya Jawab Dasar-Dasar Jurnalistik, Bandung: ARMICO, 1981.

J.S Badudu, dan Sutan Mohammad Zain, Kamus Bahasa Indonesia umum. Cet ke-4 Jakarta: Pustaka Sinar Harapan , 2001.

Komaruddin, Kamus Karya Tulis Ilmiah Jakarta: Bumi Aksara, 2006.

Kusumaningrat, Hikmat. Kusumaningrat, Purnama, Jurnalistik Teori dan Praktek, Bandung: PT Remaja Rosdakarya, 2005.

Lembaga Pengkajian Kebudayaan Nusantara (LPKN), Kamus Besar Ilmu Pengetahuan. Jakarta, 1997.

Majalah SULUH: Billingual Interfaith Magazine, Edisi 43, 44, 45, 46, 47 dan 48 Tahun 2009. 
126 Jurnal Dakwah dan Komunikasi. Vol 5 no 2, 2020

Moertopo, Ali, Strategi Kebudayaan. Jakarta: CSIS, 1978.

Muflihah, Atina, Strategi Pemasaran Radar Jogja dalam Memperluas Pasar di Yogyakarta. Yogyakarta: UIN Sunan Kalijaga, 2007.

Ngafuan Muhammad. Memburu Uang Dengan Jurnalistik, Solo: CV. Aneka Ilmu, 1995.

Patmono S. K, Teknik Jurnalistik, Jakarta: BPK Gunung Mulia, 1996.

Syamsul Asep M. Romli, Jurnalistik Praktis Untuk Pemula. Bandung: PT. RosdaKarya, 2006.

Santana Septiawan Kurniawan., Jurnalisme Investigasi, Jakarta: Yayasan OBOR Indonesia. $\mathrm{tt}$ 